Галаган В. І., к.військ.н., доцент;

Полішко С. В. к.т.н., с.н.с.;

Бондарчук С. В.

Центр воєнно-стратегічних досліджень Національного університету оборони України імені Івана Черняховського, Київ

\title{
Застосування систем підтримки прийняття рішень в управлінні нерухомим військовим майном Збройних Сил України
}

Резюме. Стаття присвячена аналізу проблемних питань процесу прийняття рішень в управлінні нерухомим військовим майном Збройних Сил України. Наведена класифікація систем підтримки прийняття рішень (СППР) базується на розгляді їх особливостей, що дає змогу визначити основні вимоги функціонування СППР в управлінні нерухомим військовим майном.

Ключові слова: система підтримки прийняття рішень; управління нерухомим майном; вимоги функціонування; військове майно.

Постановка проблеми. На сьогодні в Збройних Силах України продовжується впровадження автоматизованих комп'ютерних систем різного призначення.

Однією з найбільш розвинених систем $\epsilon$ Єдина система управління адміністративногосподарчими прочесами Збройних Сил Украӥни, яка забезпечує відкритість і прозорість адміністративно-господарської діяльності 3С України, оптимізацію процесів планування, розподілу та використання фінансових, матеріальних й інших ресурсів для забезпечення життєдіяльності військ. Загалом, ЄАСУ АГП надає достовірну інформацію, необхідну для прийняття управлінських рішень керівництвом ЗС України.

ЄCУ АГП ЗС України - $\epsilon$ першою ERPсистемою не лише в Збройних Силах, але і в силових відомствах України.

За основу для розроблення, було використано передовий світовий аналог у цивільному секторі (ідеологія ERP-систем управління ресурсами підприємств), який виявився ефективним i для військового сектору.

Нині найбільший розвиток отримала підсистема управління нерухомим майном, яка $є$ однією зі складових Єдиної системи управління адміністративно-господарчими процесами Збройних Сил України.

Швидкому впровадженню, вказаної підсистеми, сприяють певні умови. По-перше соціальна актуальність. Особливо, це стосується питань обліку об' єктів нерухомості та земельних ділянок, продажу надлишкового майна. Прозорість роботи в підсистемі зводить до мінімуму можливість зловживань у цій сфері. По-друге - відсутність обмежень щодо доступу та обміну інформацією з іншими підсистемами. Вказана підсистема не потребує додаткового створення та застосування комплексних систем захисту інформації, що значно здешевлює вартість проекту та спрощує процедуру налаштування доступу до інформації відповідно до посадових обов' язків. Система має свої потужні засоби щодо розмежування доступу до циркулюючої інформації.

Таким чином, аналіз та отриманий досвід у ході реалізації проекту показав, що сьогодні для управління адміністративно-господарчою діяльністю Збройних Сил альтернативи ERPсистемам немає.

Крім того, впровадження в Збройних Силах процесу оборонного планування неможливе без взаємопов'язаних автоматизованих систем. Основними завданнями оборонного планування визначене впровадження автоматизованих систем для оцінювання забезпеченості всіма видами ресурсів, ефективності використання, моделювання перспективних структур та інтеграції цих систем до системи інформаційної підтримки прийняття рішень $[1,2]$.

Ступінь розробленості проблеми. На сьогодні система підтримки прийняття рішень (СППР) в управлінні нерухомим військовим майном Збройних Сил України знаходиться на етапі розвитку. Основу цієї системи складає інформаційна база об'єктів нерухомості, які знаходяться на балансі Збройних Сил України та реалізована в підсистемі управління 
нерухомим військовим майном, яка прийнята в постійну експлуатацію.

Тим часом, використовуючи інформацію 3 підсистеми є можливість тільки частково (не повною мірою) задовольнити потреби, які необхідні для повноцінного та ефективного функціонування системи підтримки прийняття рішень (СППР) в управлінні нерухомим військовим майном.

Виходячи 3 викладеного, основною метою статті $€$ виявлення проблемних питань процесу прийняття рішень в управлінні нерухомим військовим майном, розгляд та можливість використання систем підтримки прийняття рішень (СППР), визначення основних вимог до їх функціонування.

Виклад основного матеріалу. Теоретичні дослідження щодо розроблення перших систем підтримки прийняття рішень проводилися в технологічному інституті Карнегі, на прикінці 50-х початку 60-х років XX століття. Об'єднати теорію 3 практикою вдалося фахівцям 3 Массачусетського технологічного інституту в 60-х роках. У середині та наприкінці 80-х років XX століття стали з'являтися такі системи, як EIS, GDSS, ODSS. У 1987 році компанія Texas Instruments розробила для авіаперевізника United Airlines систему контролю за повітряними суднами (Gate Assignment Display System). Це дало змогу значно знизити збитки від польотів i відрегулювати управління різними аеропортами, починаючи від Міжнародного aepoпорту O’Hare в Чикаго i закінчуючи Stapleton у Денвері, штат Колорадо. У 90-х роках сфера можливостей СППР розширювалася завдяки впровадженню сховищ даних i інструментів OLAP. Нові технології звітності зробили СППР незамінною в менеджменті.

Нині розвиток інформаційних технологій призвів до того, що система підтримки прийняття рішень або СППР (Decision Support Systems - DSS) - це комп'ютерна система, яка шляхом збору та аналізу великої кількості інформації може впливати на процес прийняття рішень організаційного плану в бізнесі та підприємництві [3].

Інтерактивні системи дають змогу керівникам отримати корисну інформацію 3 першоджерел, проаналізувати іiі, а також виявити існуючі бізнес-моделі для вирішення певних завдань. За допомогою СППР можна простежити за всіма доступними інформаційними активами, отримати порівняльні значення обсягів продаж, спрогнозувати дохід організації при гіпотетичному впровадженні нової технології, а також розглянути всі можливі альтернативні рішення.

Основними чинниками, в результаті дії яких виникла можливість створення та використання СППР, є:

- ускладнення економічних та соціальних систем;

- підвищення ціни управлінських рішень;

- розвиток конкуренції призвів до зменшення часу на прийняття рішень;

- засоби, що затрачені на аналіз інформації та прийняття більш якісного рішення, багаторазово себе виправдовують.

Для детального аналізу функціональності СППР необхідно розглянути діяльність командирів (начальників) та, відповідно, управлінських рішень (УР) які вони приймають.

Класифікація УР необхідна для визначення загальних та конкретноспецифічних підходів до їх розроблення, реалізації та оцінки, що дає змогу підвищувати їх якість, ефективність, сутність та може бути підгрунтям для розроблення та налагодження СППР (рис. 1).

Найбільш важливим для досягнення мети функціонування СППР може бути класифікація УР за функиіональним змістом, тобто відносно спільної функції управління [4]: планові; організаційні; контролюючі; прогнозні.

Зазвичай, такі рішення відносяться, тією чи іншою мірою, до всіх функцій управління, однак у кожному 3 них можна виділити основну направленість, пов'язану 3 однією основною функцією.

Класифікація, що пов' язана $з$ характером задач, що розв'язуються, може включати: економічні; організаційні; технологічні; технічні; екологічні та інші.

Частіше всього, УР пов' язані не з однією, a 3 рядом задач, що мають комплексний характер.

За рівнями ієрархії систем управління виділяють УР: на рівні систем; на рівні підсистем; на рівні окремих елементів системи. Зазвичай ініціюються загальносистемні рішення, які потім доводяться до елементарного рівня, однак, можливий i зворотній варіант.

Залежно від організачї розроблення рішень виділяються такі УР: особисті; колегіальні; колективні. 


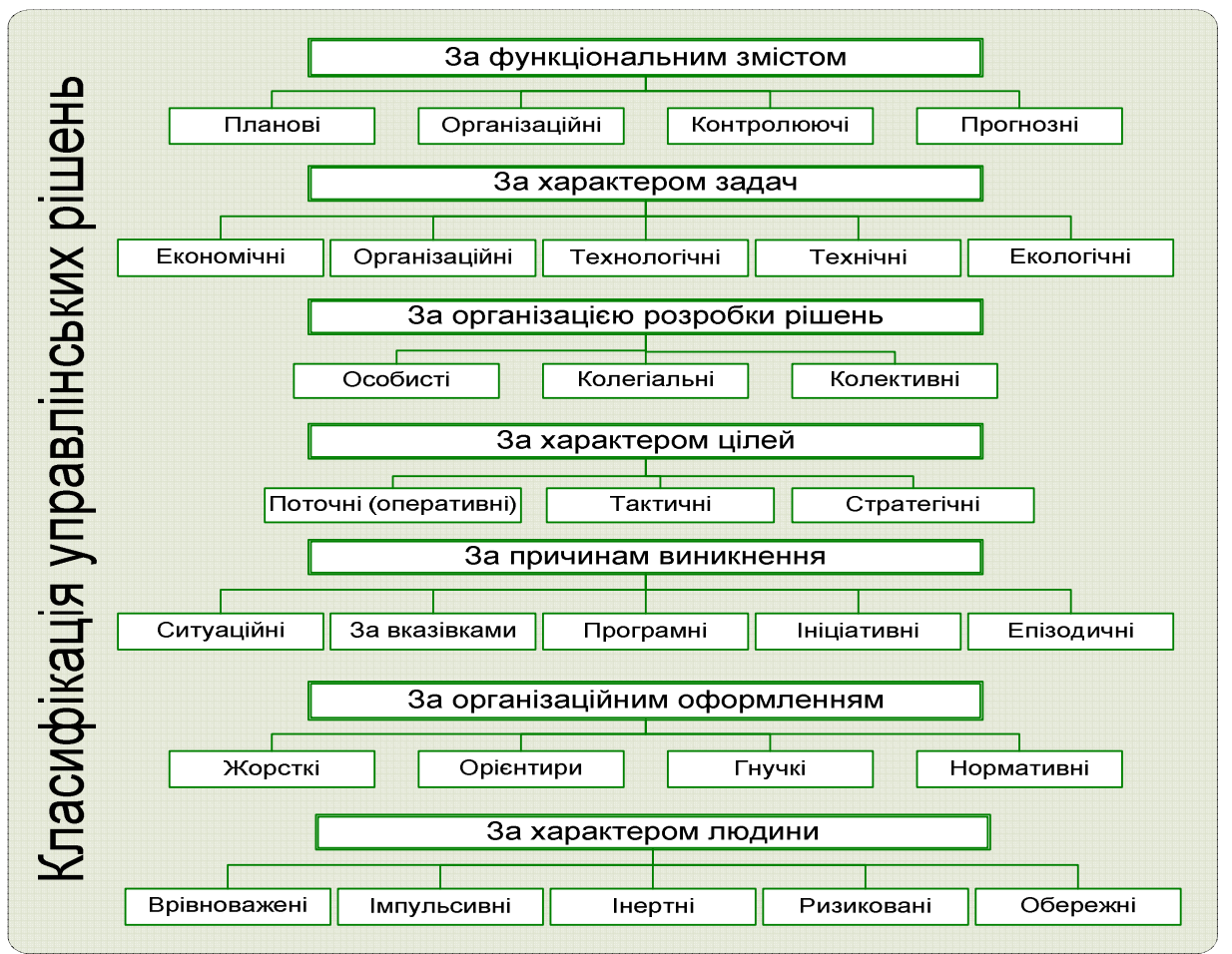

Рис.1. Класифікація управлінських рішень

Перевага вибору способу організації виробки УР залежить від багатьох причин: компетенції керівника (начальника), рівня кваліфікації колективу структурного підрозділу, характеру задач, ресурсів тощо.

За характером иілей рішення, що приймаються, можуть бути як: поточні (оперативні); тактичні; стратегічні.

За причинам виникнення УР поділяються на:

- ситуаційні, пов'язані 3 характером обставин, що виникли;

- за вказівками (розпорядженнями) вищих керівників (органів);

- програмні, пов'язані 3 включенням даного об' єкта управління в певну структуру програмно-цільових відносин, заходів;

- ініціативні, пов'язані 3 проявом ініціативи системи - не зовсім характерні для збройних сил, але в деяких випадках можуть застосовуватися;

- епізодичні та періодичні - витікають 3 обставин повсякденної діяльності військ (сил).

За організачійним оформленням УР поділяться на:

- жорсткі, однозначно задають подальший шлях їх втілення;

- орієнтири, що визначають напрям розвитку системи;

- гнучкі, що змінюються відповідно до умов функціонування та розвитку системи;

- нормативні, які задають параметри протікання процесів у системі.
Оскільки рішення приймаються людьми, то їх характер багато в чому несе за собою відбиток особистості (управлінця), причетного до їх появи.

У зв'язку з цим прийнято розрізняти врівноважені, імпульсивні, інертні, ризиковані та обережні рішення.

Врівноважені рімення приймають командири (начальники), які уважно і критично відносяться до своїх дій, висунутим гіпотезам та їх перевірці. Як правило, перш ніж приступити до прийняття рішення, вони мають сформульовану вихідну ідею.

Імпульсивні рішення, автори яких легко генерують найрізноманітніші ідеї в необмеженій кількості, але не в стані їх як слід перевірити, уточнити, оцінити. Такі рішення виявляються недостатньо обгрунтованими i надійними.

Інертні рішення $€$ результатом обережності. У них навпаки контрольні та уточнюючі дії переважають над генерацією ідей, тому в таких рішеннях важко виявити оригінальність та новаторство.

Ризиковані рішення відрізняються від імпульсивних тим, що їх автори не потребують вдалого обгрунтування своїх гіпотез i, якщо впевнені в собі, можуть не боятися будь-яких небезпек.

Обережні рішення характеризуються клопітливою оцінкою командиром (начальником) всіх варіантів, надкритичним підходом до справи. Вони меншою мірою, ніж 
інертні, відрізняються новизною i оригінальністю.

Перераховані види вирішень приймаються, в основному, в процесі оперативного управління підлеглими (персоналом). Для стратегічного та тактичного управління будь-якими підсистемами системи управління приймаються раціональні рішення, які повинні базуватися на методах економічного аналізу, обгрунтування та оптимізації.

Рішення командира (начальника) може приймати ряд форм і представити: стандартне рішення, при прийнятті якого існує фіксований набір альтернатив; бінарне рішення (так або ні); багатоваріантне рішення (має дуже широкий спектр альтернатив); інноваційне рішення - коли потрібно вжити заходів, але немає прийнятних альтернатив.

Для допомоги i полегшення процесу прийняття обгрунтованих рішень та зменшення впливу людського фактора i направлена СППР, яка призначена перш за все для підтримки багатокритеріальних рішень у складному інформаційному середовищі.

Під багатокритеріальністю розуміється той факт, що результати прийнятих рішень оцінюються не за одним, а за сукупністю багатьох показників (критеріїв), які розглядаються одночасно.

Інформаційна складність визначається необхідністю обліку великого обсягу даних, обробка яких без допомоги сучасної комп'ютерної техніки практично не можлива. У цих умовах множина можливих рішень, як правило, досить велика, i вибір найкращих 3 них, без детального аналізу може призвести до грубих помилок.

Система підтримки вирішення СППР вирішує два основні завдання:

вибір найкращого рішення 3 безлічі можливих (оптимізація);

упорядкування можливих рішень за перевагою (ранжування).

У кожному завданні першим i найважливішим моментом є вибір сукупності критеріїв, на основі яких у подальшому будуть оцінюватися і порівнювати можливі рішення (альтернативи).
СППР $є$ комплексом програмних інструментальних засобів для аналізу даних, моделювання, прогнозування та прийняття управлінських рішень, що може складатися 3 власних розробок організації та придбаних програмних продуктів (Oracle, IBM, Cognos, Qlik View).

За класифікацією СППР можна виділити (рис.2):

\section{за взаємодією з користувачем:}

- пасивні - допоможуть у прийнятті рішень, але не можуть висунути конкретні пропозиції;

- активні - безпосередньо беруть участь у розробленні правильного рішення;

- кооперативні - передбачають взаємодію СППР 3 користувачем. Надану системою пропозицію командир (начальник) може доопрацювати, вдосконалити, а потім відправити назад у систему для перевірки. Після цього пропозиція знову надається користувачеві, і так доти, поки він не узгоджує рішення.

за способом підтримки:

- модельно-орієнтовані,

що використовують у роботі доступ до статистичних, фінансових або інших моделей;

- засновані на комунікаціях підтримують роботу двох i більше користувачів, що займаються спільними завданням;

- орієнтовані на дані, що мають доступ до тимчасових рядів структури (організації) та використовують у роботі не тільки внутрішні, але й зовнішні дані;

- орієнтовані на документи маніпулюють неструктурованою інформацією, що знаходиться в різних електронних форматах;

- орієнтовані на знання - надають спеціалізовані рішення проблем, заснованих на фактах.

за сферою

використання:

загальносистемні; настільні.

Загальносистемні системи працюють 3 великими системами зберігання даних i застосовуються багатьма користувачами. Настільні є невеликими системами і підходять для управління 3 персонального комп'ютера одного користувача. 


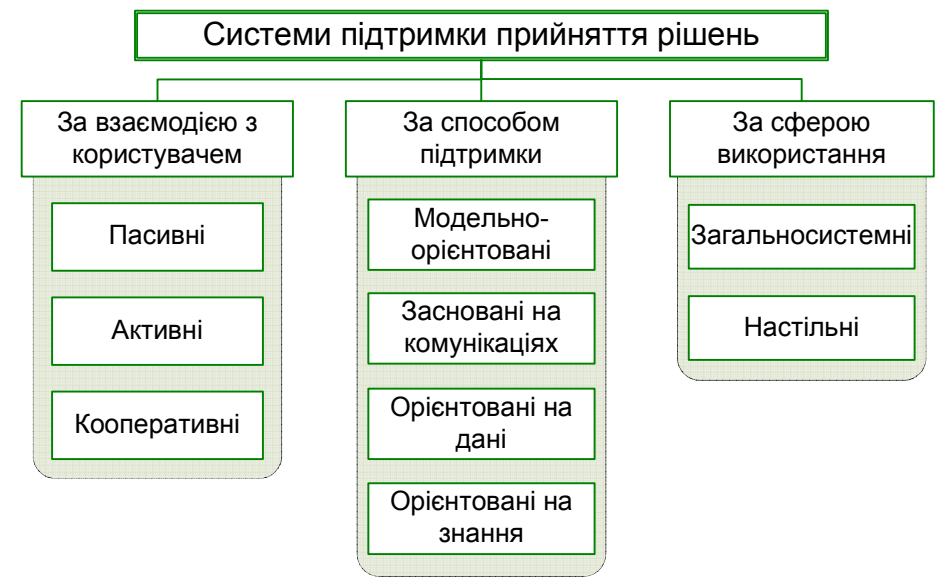

\section{Рис.2. Класифікація систем підтримки прийняття рішень}

Водночас, разом із детальним аналізом та визначенням характеристик систем підтримки прийняття рішення необхідно розглядати i структури, що здійснюють управління нерухомістю, як подальшого об'єкта автоматизації.

Враховуючи, що управління нерухомим військовим майном передбачає комплексний підхід до розвитку та управління військовою нерухомістю, то і розподіл обов'язків між суб' єктами господарювання повинен мати чітку ієрархію.

Збройні Сили України використовують державні ресурси та майно, до яких відноситься i нерухомість. Державна нерухомість, яка передана для використання військом знаходиться на балансі Головного квартирно-експлуатаційного управління $3 \mathrm{C}$ України, яке в свою чергу передає іï для користування військовим органам управління (частинам) на умовах безоплатної оренди. Зрозуміло, що обидві структури (ГоловКЕУ 3С України та військові частини) $\epsilon$ користувачами державного майна. Тим часом, необхідно чітко розмежувати їх функції. На наш погляд, за ГоловКЕУ ЗС України залишаються функції ухвалення стратегічних рішень і контролю за якістю їх виконання. Функції оперативного управління делегуються органам військового управління (частинам).

Такий підхід дає змогу вирішувати завдання, пов'язані зі створенням, розвитком, оцінкою і управлінням нерухомістю в цілях реалізації інтересів держави. Найбільш актуальним це питання $є$ у ході проведення антитерористичної операції на сході України, коли проводяться масштабні зміни в чисельності збройних сил, створення нових та переміщення існуючих військових структур, будівництво та перебудова об'єктів нерухомості.

Використовуючи класифікацію та на основі теоретичних напрацювань та практичного досвіду $\epsilon$ можливість визначити основні вимоги функціонування СППР в управлінні нерухомим військовим майном, на які необхідно звернути увагу, ще в ході іiі розроблення.

До таких можна віднести:

- можливість

використання слабостуктурованих та нечітких даних;

$$
\text { - можливість оперувати }
$$

слабостуктурованими рішеннями;

- підтримувати як взаємозалежні, так i послідовні рішення;

- можливість застосовувати зовнішні бази даних (знання);

- підтримувати моделювання та

прогнозування;

- проста у застосуванні та модифікації;

- підтримувати три фази процесу прийняття рішень: інтелектуальну частину, проектування та вибір;

- повинна бути призначена для різного рівня (начальник ГоловКЕУ, начальники управлінь, начальники КЕВ (КЕЧ);

- може бути адаптована до індивідуального та групового застосування;

- виявляти гнучкість і адаптуватися до змін у структурі;

- підвищувати ефективність процесу прийняття рішень.

Висновки. Таким чином, правильний вибір СППР дає змогу полегшити роботу керівників (начальників) та підвищити ії ефективність. Вони значно спрощують розв'язання проблем у повсякденній діяльності. На основі СППР можна проводити навчання щодо управління нерухомістю та здійснювати підготовку кадрів.

Ці інформаційні системи дають змогу підвищувати контроль над діяльністю структури (організації) щодо управління об'єктами нерухомості. Наявність чітко функціонуючої СППР дає великі переваги у порівнянні зі звичним процесом прийняття 
рішення. Завдяки пропозиціям, висунутим СППР, можуть відкриватися нові підходи до вирішення повсякденних та нестандартних завдань, які покладені на структури 3С України щодо управління нерухомістю.

Подальші дослідження за цією тематикою доцільно зосередити на розширенні означених в статті загальних підходів до вибору СППР, які направлені на процеси управління нерухомістю в $3 \mathrm{C}$ України.

\section{СПИСОК ВИКОРИСТАНОЇ ЛІТЕРАТУРИ}

1. Закон України "Про організацію оборонного планування” / Відомості Верховної ради
України - Офіц. вид. - К., 2005. - 97 с. (Бібліотека офіційних видань).

2. Стратегічний оборонний бюлетень України на період до 2015 року / Міністерство оборони України. - К., 2004. - 64 с. - (Бібліотека офіційних видань).

3. Системы поддержки принятия решений: учебник и практикум для бакалавриата и магистратуры / В. Г. Халин [и др.] ; под ред. В. Г. Халина, Г. В. Черновой.- М. : Издательство Юрайт, 2017. 494 с. - (Серия : Бакалавр и магистр. Академический курс).- ISBN 978-5-534-01419-8.

4. Системы поддержки принятия решений: учебное пособие / Уринцов А. И, Дик В. В - М. : МЭСИ, 2008. $-230 \mathrm{c}$.

Стаття надійшла до редакції 20.01.2018

Галаган В. И., к.воен.н., доцент;

Полишко С. В., к.т.н., с.н.с.;

Бондарчук С. В.

Центр военно-стратегических исследований Национального университета обороны Украины имени Ивана Черняховского, Киев

Применение систем поддержки принятия решений в управлении недвижимым военным имуществом Вооруженных Сил Украины

Резюме. Статья посвящена анализу проблемных вопросов процесса принятия решений в управлении недвижимым военным имуществом Вооруженных Сил Украины. Приведенная классификация систем поддержки принятия решений (СППР) базируется на рассмотрении их особенностей, позволяет определить основные требования функционирования СППР в управлении недвижимым военным имуществом.

Ключевые слова: система поддержки принятия решений; управления недвижимым имуществом; требования функционирования; военное имущество.

\section{Galagan, PhD (Military), assistant professor ;}

S. Polishko, PhD (Technical), senior researcher;

\section{S. Bondarchuk}

Center for Military and Strategic Studies of the National Defence University of Ukraine named after Ivan Cherniakhovskyi, Kyiv

Application of support systems for decision-making in the management of the real property of the Armed Forces of Ukraine

Resume. The article is devoted to the analysis of problem issues of the decision-making process in the management of the real property of the Armed Forces of Ukraine. The given classification of decision support systems (DSS) is based on consideration of their features, it allows us to determine the basic requirements for the functioning of the DSS in the management of immovable military property.

Keywords: decision support system; real estate management; operational requirements; military property. 